\title{
Substrate rugosity and temperature matters: patterns of benthic diversity at tropical intertidal reefs in the SW Atlantic
}

\author{
Ana Carolina A Mazzuco ${ }^{\text {Corresp., } 1}{ }^{1}$, Patricia S Stelzer ${ }^{1}$, Angelo F Bernardino ${ }^{1}$ \\ ${ }^{1}$ Department of Oceanography, Universidade Federal do Espírito Santo, Vitória, Espírito Santo, Brazil \\ Corresponding Author: Ana Carolina A Mazzuco \\ Email address: ana.mazzuco@ufes.br
}

Modeling and forecasting ocean ecosystems in a changing world will require advances in observational efforts to monitor marine biodiversity. One of the observational challenges in coastal reef ecosystems is to quantify benthic and climate interactions which are key to community dynamics across different habitats. However, habitat complexity (i.e. substrate rugosity) on intertidal reefs can be an important variable explaining benthic diversity and taxa composition, but the association of substrate and seasonal variability is poorly understood on lateritic reefs on the South Atlantic. We asked if benthic assemblages on intertidal reefs with distinct substrate rugosity would follow similar seasonal patterns of succession following meteo-oceanographic variability in a tropical coastal area of Brazil. We combined an innovative 3D imaging for measuring substrate rugosity with satellite monitoring to monitor spatio-temporal patterns of benthic assemblages. The dataset included monthly in situ surveys of substrate cover and taxon diversity and richness, temporal variability in meteo-oceanographic conditions, and reef structural complexity from four sites on the Eastern Marine Ecoregion of Brazil. Additionally, correlation coefficients between temperature and both benthic diversity and community composition from one year of monitoring were used to project biodiversity trends under future warming scenarios. Our results revealed that benthic diversity and composition on intertidal reefs are strongly regulated by surface rugosity and sea surface temperatures, which control the dominance of macroalgae or corals. Intertidal reef biodiversity was positively correlated with reef rugosity which supports previous assertions of higher regional intertidal diversity on lateritic reefs that offer increased substrate complexity. Predicted warming temperatures in the Eastern Marine Ecoregion of Brazil will likely lead to a dominance of macroalgae taxa over the lateritic reefs and lower overall benthic diversity. Our findings indicate that rugosity is not only a useful tool for biodiversity mapping in reef intertidal ecosystems but also that spatial differences in rugosity would lead to very distinct biogeographic and temporal patterns. This study offers a unique baseline of benthic biodiversity on coastal marine habitats that is complementary to worldwide efforts to Peer) reviewing PDF | (2019:07:39107:3:0:CHECK 14 Nov 2019) 
improve monitoring and management of coastal reefs. 
1 Substrate rugosity and temperature matters: patterns

2 of benthic diversity at tropical intertidal reefs in the

3 SW Atlantic

Corresponding Author

Ana Carolina Mazzuco ${ }^{1}$

Av. Fernando Ferrari 514 Goiabeiras, Vitória, Espírito Santo, 29075-910, Brazil

Email: ana.mazzuco@ufes.br

\section{Abstract}

Modeling and forecasting ocean ecosystems in a changing world will require advances in observational efforts to monitor marine biodiversity. One of the observational challenges in coastal reef ecosystems is to quantify benthic and climate interactions which are key to community dynamics across different habitats. However, habitat complexity (i.e. substrate rugosity) on intertidal reefs can be an important variable explaining benthic diversity and taxa composition, but the association of substrate and seasonal variability is poorly understood on lateritic reefs on the South Atlantic. We asked if benthic assemblages on intertidal reefs with distinct substrate rugosity would follow similar seasonal patterns of succession following meteooceanographic variability in a tropical coastal area of Brazil. We combined an innovative 3D imaging for measuring substrate rugosity with satellite monitoring to monitor spatio-temporal patterns of benthic assemblages. The dataset included monthly in situ surveys of substrate cover and taxon diversity and richness, temporal variability in meteo-oceanographic conditions, and reef structural complexity from four sites on the Eastern Marine Ecoregion of Brazil.

Additionally, correlation coefficients between temperature and both benthic diversity and community composition from one year of monitoring were used to project biodiversity trends under future warming scenarios. Our results revealed that benthic diversity and composition on intertidal reefs are strongly regulated by surface rugosity and sea surface temperatures, which control the dominance of macroalgae or corals. Intertidal reef biodiversity was positively correlated with reef rugosity which supports previous assertions of higher regional intertidal diversity on lateritic reefs that offer increased substrate complexity. Predicted warming temperatures in the Eastern Marine Ecoregion of Brazil will likely lead to a dominance of macroalgae taxa over the lateritic reefs and lower overall benthic diversity. Our findings indicate that rugosity is not only a useful tool for biodiversity mapping in reef intertidal ecosystems but also that spatial differences in rugosity would lead to very distinct biogeographic and temporal 
40

patterns. This study offers a unique baseline of benthic biodiversity on coastal marine habitats that is complementary to worldwide efforts to improve monitoring and management of coastal reefs.

\section{Keywords}

marine biodiversity, macroalgae, spatiotemporal variations, rugosity, sea surface temperature, tropical reefs

\section{Introduction}

Marine benthic ecosystems hold a significant portion of global biodiversity that is mostly concentrated in threatened coastal habitats such as intertidal reefs (Halpern et al., 2008; Andrades et al., 2018). There are high concerns of human impacts on marine biodiversity across a range of expected climate change scenarios (Dulvy et al., 2003; Solan et al., 2004; Harnik et al., 2012; McCauley et al., 2018). In the tropics, forecasts point towards extreme climate-driven environmental conditions and severe biodiversity losses in the near decades (Cheung et al., 2009; Bellard et al., 2012; Bathiany et al., 2018). Understanding how patterns of biodiversity respond to increasing temperatures and subsequent oceanic-climatic changes is an important step towards effective management and conservation of marine ecosystems (Santamaría \& Mendéz, 2012; Muelbert et al., 2019).

In benthic marine communities, substrate and oceanographic parameters are critical predictors of the distribution and abundance of species, setting biodiversity patterns at multiple spatio-temporal scales and contribute to shaping observed biodiversity patterns (Menge et al., 1997; Weiters et al., 2009; Burrows et al., 2008; Blanchette et al., 2008; Griffiths et al., 2017). The strength of regulating factors at each location is linked to ecosystem dynamics (Navarrete et al., 2005), incorporating both local (e.g. substrate, productivity) and large-scale climatic and oceanographic conditions (e.g. Steneck \& Deither, 1994; Menge et al., 2003; Zawada et al., 2010; Piacenza et al., 2015; Mazzuco et al., 2019). On rocky shores, wave exposition and changes in sea temperature are major factors structuring and regulating benthic communities at multiple scales (e.g. Burrows et al., 2008; Blanchette et al., 2008; Creswell et al., 2017). In the intertidal zone, the reef physical structure and complex topography significantly influence the distribution, zonation and overall benthic biodiversity (e.g. Archambault \& Bourget, 1996; Ferreira et al., 2001; Marias et al., 2010; Bloch \& Klingbeil, 2016). Therefore, coupling benthic and pelagic approaches will likely improve the ecological modeling of benthic communities and increase the success of modeling spatio-temporal variations and losses in biodiversity under a changing climate (Griffiths et al., 2017).

Temperature is a major driver of intertidal benthic biodiversity (e.g. Thompson et al., 2002; Hiscock et al., 2004; Morelissen \& Harley, 2007; Harley, 2011; Meager et al., 2011; Kordas et al., 2015). Air and sea temperatures regulate spatio-temporal patterns of the whole in the intertidal zone by creating a gradient of environmental conditions (Sunday et al., 2019; Wallingford \& Sorte, 2019). Higher temperatures reduce intertidal biodiversity, particularly 
80

when temperatures overcome species' physiological limits (e.g. Kelmo et al., 2014; Wethey et al., 2011; Vafeiadou et al., 2018; Starko et al., 2019). In coral reef communities, increased temperatures negatively affect intertidal biodiversity due to coral mortality (Anthony \& Kerwell, 2007; Smit \& Glassom, 2017). While in temperate and upwelling rocky shores, warmer temperatures may have positive influences on overall biodiversity (Valdivia et al., 2013; Puente et al., 2017; Lami et al., 2018). However, the relationship between temperature fluctuations and biodiversity patterns can be variable between marine ecosystems. (e.g. Olabarria et al., 2013; Kordas et al., 2015; Meadows et al., 2015; Puente et al., 2017; Sorte et al., 2017), and as a result, greatly change predictions of how climate change scenarios will impact global coastal biodiversity.

Rugosity is likewise a key-variable for intertidal biodiversity as it creates a range of micro-habitats that promotes species coexistence, so increased rugosity is expected to have a positive impact on the diversity of intertidal communities (e.g. Londoño-Cruz et al., 2014; Dias et al., 2018; Leclerc et al., 2018; Price et al., 2019). Habitat complexity explains spatial changes in species distribution and assemblage composition along coastal regions (Guichard et al., 2001; Cruz-Mota et al., 2010; Zawada et al., 2010; Bloch \& Klingbeil, 2016) and can overcome other seascape variables in the regulation of biodiversity (Fuchs, 2013; Meißner et al., 2014; Williams et al., 2015). However, reef rugosity is not often used as a metric for coastal monitoring and less is known about how benthic assemblages at variable levels of reef rugosity respond to seasonal meteo-oceanographic variations (Meager \& Schlacher, 2013). Understanding variability within and between habitat types is crucial to improve ecological models and impact management applications (Huntington et al., 2010; McArthur et al., 2010; Kovalenco et al., 2012).

Rocky shores are ubiquitous along the Brazilian Atlantic coast, but they vary widely in their substrate structure and are also exposed to a range of climatic conditions. In the Eastern Brazil Marine Ecoregion, decadal temperatures exhibit significant warming trends that are likely to impact coastal marine biodiversity (Bernardino et al., 2015). Rocky lateritic (or sandstone) rocks are ubiquitous in the Eastern Brazil Marine Ecoregion and further north, whereas granite rocky coasts predominate in the southern sub-tropical coast. Reefs of lateritic sandstones are highly topographically complex and understudied globally when compared to granite reefs (Amaral \& Jablonski, 2005; Coutinho et al., 2016). Lateritic reefs are potentially transitional habitats with typical rocky shore features but with highly eroded substrate (sandstone) interspaced by calcareous formations (Albino et al., 2016). Given a distinct substrate rugosity, lateritic reefs hold a singular and diverse benthic community dominated by macroalgal beds with several calcareous habit-forming species (O’Hara, 2001; Guidetti et al., 2004; Azzarello et al., 2014). Although community structure varies among reefs and throughout the year, the environmental mechanisms associated with such variability remain uncertain in this marine ecoregion of Brazil.

Unlike temperate and equatorial rocky shores, where increases in sea temperatures are causing biodiversity losses (Smith et al., 2006; Hawkins et al., 2009; Jueterbock et al., 2013), lateritic reefs may experience an increase in overall biodiversity during warmer periods since these reefs host a number of both tropical and subtropical species. In subtidal tropical reefs, 
121

122

123

124

125

126

127

128

129

130

131

132

133

134

135

136

137

138

139

140

141

142

143

144

145

146

147

148

149

150

151

152

153

154

155

156

157

158

159

160

161

warmer temperatures have been suggested to lead to an overall increase in taxa richness when compared to equatorial or subtropical regions (Aued et al., 2018). If temporal trends of diversity with observed warming at the coastal intertidal reefs are confirmed, these ecosystems will likely experience significant changes in the dominance of benthic taxa with marked functional changes (Poloczanska et al., 2016). For example, a decrease in macroalgae taxa and increase in anthozoans with warmer temperatures would not only change the current dominant habitatforming species but also would impact food provisioning for a number of coastal benthic and pelagic organisms (Andrades et al., 2019; Mazzuco et al., 2019). These transitional intertidal communities may respond to temperature with varying levels of relisience depending on their structure and dynamics (Bernhardt and Leslie, 2013; Timpane-Padgham et al., 2017; Palumbi et al. 2019).

Accessing and predicting changes in biodiversity from local to global scales is a high research priority. Several ocean observatories are incorporating biodiversity among their monitored variables to meet multiple-stakeholder needs (Bax et al., 2019; Mulbert et al., 2019). Standard protocols and technology to improve and speed biodiversity data collection are highlighted as potential solutions to monitor biodiversity at large scales and with high temporal resolution (Canonico et al., 2019). Associating abiotic surrogates and marine biodiversity change is an important tool to support forecasts in global change scenarios (Canonico et al., 2019). Satellite remote sensing products are adequate for biodiversity synoptic approaches, providing a reliable framework for different coastal regions (Capotondi et al., 2019). Finding current drivers of biodiversity change across marine habitats is fundamental to give us a better understanding of the expected patterns of biodiversity in the present and future.

Considering the importance of understanding and forecasting shifts in the marine community, this study aims to: (I) provide the first 1-year baseline assessment of benthic assemblage composition and diversity of intertidal lateritic reefs on the Eastern Marine Ecoregion of Brazil; (ii) evaluate the role of substrate complexity and oceanic-climatic variables to benthic assemblage variability; (iii) integrate assemblage multivariate covariance factors to predict future biodiversity changes in these coastal reefs in warming scenarios for the Eastern Marine Ecoregion of Brazil. We tested the hypothesis that rugosity would have a positive influence on local benthic biodiversity, but that these effects would change temporally due to climate forcing. We expected that temperature would have a stronger effect on the variability of benthic taxa compared to the other oceanographic parameters, therefore we expected that projected warming would be a driver of assemblage composition in different climatic scenarios.

\section{Materials \& Methods} Study area

This study was carried out in a marine protected area in the Eastern Brazil Marine Ecoregion (Área de Proteção Costa das Algas; environmental permit by Instituto Chico Mendes \#57819-1; Fig. 1). The coastal zone is characterized by dispersed intertidal lateritic reefs with abundant macroalgal and rhodolith beds. Coastal oceanographic conditions are typically influenced by E-NE winds from the South Atlantic high-pressure system, strong internal tidal 
162

163

164

165

166

167

currents, and E-SE wave swells (Pereira et al., 2005; Pianca et al., 2010). Meteorological cold fronts occur periodically and influence the vertical mixing of the water column and wave action on the coast (Pianca et al., 2010). Episodic upwelling events occur mostly during spring and summer (Pereira et al., 2005). This is a tropical region with an average air temperature of $25^{\circ} \mathrm{C}$ that has experienced significant warming trends in the last four decades (Bernardino et al., 2015; Bernardino et al., 2016).

We monitored benthic assemblages of four intertidal reefs (study sites ) monthly from December 2017 to August 2018 (Fig. 1; sampling dates in Supplementary material Table S1). These sites are similar in their presence of lateritic substrate, geographical orientation (i.e. to the East), moderate exposure to wave action, and are under similar anthropogenic pressure (i.e. located near small human settlements with no direct sewage disposal to the reef area).

\section{Benthic biodiversity and substrate structure}

Reef benthic biodiversity (incrusting and slow mobile taxa) was estimated monthly at each site along four replicated 20 -m length photo-transects using a GoPro ${ }^{\circledR}$ camera. Images were obtained by photographing from above the area delimited by a $0.5 \mathrm{~m} \times 0.5 \mathrm{~m}$ quadrat, taking 10 photos at every $2 \mathrm{~m}$ along the transect. Transects were positioned parallel to the reef fringe approximately 5 meters apart. Images were processed in Coral Point Count with Excel Extensions Software (CPCe) where benthic organisms (primary cover) were visually identified under 20 random points within a 100 point grid (Carleton and Done, 1995; Lenth, 2001). Quality control of the photo-processing included multiple reviewers (3) analyzing photograph subsets and in situ validation.

The substrate rugosity of the intertidal reefs was measured once at each reef by determining the linear roughness (R) through 3D modeling (Young et al., 2017). Carrying out rugosity measurements monthly was not logistically feasible and we assumed that reef rugosity (i.e. the substrate physical structure) was relatively stable in the temporal scale of this study. A representative intertidal area of $2 \mathrm{~m}^{2}$ positioned in the area of the photo-transects in each site was photographed digitally by a series of photos which were overlaid to build a 3D model. The camera was pointed directly to the substrate with constant height and orientation (Young et al., 2017). The 3D models of the reefs were built in Agisoft PhotoScan Standart Edition software through the following steps: (1) photo alignment, (2) cloud construction of points, (3) mesh, and (4) texture constructions. The site substrate roughness $(\mathrm{R})$ was calculated through the virtual chain method by averaging the linear contours (linear roughness, $n=6$ ) along with each 3D model using the Rhinoceros software.

\section{Meteo-oceanographic monitoring}

Meteorological and oceanographic conditions (air and sea surface temperatures AirT/SST, precipitable atmosphere water Precipitation, significant wave height $S W H$, sea surface chlorophyll-a Chla, ocean salinity Salinity) in the study region were monitored synoptically through satellite remote sensing at the local and regional scales (4 to $30 \mathrm{~km}$ ) (Table 1). The meteo-oceanographic data (AirT, SST, Precipitation, SWH, Salinity) were averaged for the study 
203 region (Área de Proteção Ambiental Costa das Algas, Long. 40.259 to $39.8 \mathrm{~W}$, Lat. $20.3^{\circ}$ to $19.8^{\circ}$

204 S). Chla was obtained for each site (Coqueiral, Long. 40.10 W, Lat. 19.93 S; Gramuté, Long.

20540.14 W, Lat. 20.02 S; E. das Garças, Long. 40.14 W, Lat. 20.06 S, Costa Bela, Long. 40.14 W, 206 Lat. $20.10 \mathrm{~S}$ ). The data available for the study area was then averaged monthly and included all 207 available data for 29-30 days prior to each sampling.

208

209

\section{Data analysis}

Temporal (monthly) differences in meteo-oceanographic conditions (AirT, SST, Precipitation, Salinity, SWH) were evaluated through a one-way balanced analysis of variance (ANOVA) (Underwood, 1997). For Chla, temporal (monthly) and spatial (sites) differences were tested using a two-way balanced ANOVA. A total of eight months were included in the ANOVAs, January/2017 samplings were not performed at all sites and were excluded from these analyses (Table S1). The number of replicates within a month varied according to the temporal resolution for each variable $(n=29$ to 30 for AirT, SST, and Precipitation; $n=672$ for SWH; $n=$ 4 for Chla; $n=3$ for Salinity). Co-variation between SST and AirT and Salinity and Precipitation were evaluated through correlation analysis (Sokal \& Rohlf, 2003). The temporal autocorrelation in meteo-oceanographic conditions was assessed by comparing each variable versus time with correlation analyses. Variables were considered autocorrelated when they were significantly correlated with time (correlation coefficient $\neq 0$ with $p \leq 0.05$ ). Only Precipitation was temporally autocorrelated; this was corrected in analyses by using the differences between the averages for consecutive time periods following Pineda and Lopez, 2002 (Table S2). Differences in reef rugosity between sites were also evaluated through a one-way balanced ANOVA, with site as a fixed factor and the linear roughness as replicates $(n=6)$. Data were transformed $(\log x+1)$ when needed to fit the assumptions of ANOVA (normality and homogeneity of variances), verified by Shapiro-Wilk's and Cochran tests. ANOVA results were complemented by post-hoc pairwise Tukey HSD tests (Tukey, 1949).

Benthic assemblages were analyzed through taxa percentage cover (\%) and multivariate analysis to test for spatial and temporal differences in assemblage composition and two univariate response variables: diversity (Shannon-Weiner index) and richness (the number of taxa).

Biodiversity variables were calculated monthly over $100.5 \mathrm{~m}^{2}$ quadrats per transect for each site, resulting in a total of 4 replicates per site per month. Differences in biodiversity were assessed through permutational multivariate analysis of variance (PERMANOVA) on 9,999 permutations of residuals under a reduced model (Anderson, 2006; Oksanen et al., 2018). The PERMANOVAs compared the variability in biodiversity among sites (factor 1, fixed, with 4 levels) and monthly (factor 2, fixed, with 8 levels), with 4 replicates each. The assemblage taxa \% cover was squareroot transformed prior to analysis to reduce the influence of abundant and rare organisms (Gotelli $\&$ Ellison, 2004). PERMANOVAs were carried out using Euclidian distance for univariate analysis (diversity and richness) and the Bray-Curtis dissimilarity for assemblage composition, and significant results were complemented by post-hoc pairwise comparisons (Anderson, 2017). 
Canonical analysis of principal coordinates (CAP) (Anderson \& Willis, 2003) complemented by multidimensional scaling (Anderson, 2001; McArdle \& Anderson, 2001; Oksanen et al., 2018) was performed to evaluate the association between biological and physical spatio-temporal patterns. The CAP was used to identify the environmental variable or group of variables that best explained the variation of benthic assemblage cover, and to determine the species that contributed most to the difference among samples (Mazzuco et al., 2019). Additionally, a canonical discriminant function analysis (DFA) was used to test spatial (i.e. between-site) differences that could be distinguished by the numerical relationship between biological and physical variables. The DFA function was built using variables with significant contributions to variability according to the CAP analysis. Substrate rugosity could not be included in the function since it is a constant value for each site. DFA results were interpreted based on the linear discriminant coefficients, which described the relationship between environmental conditions and benthic assemblage in the study region. Jackknife re-samplings were included in the analyses to test the accuracy of the classifications by DFA (Tukey, 1958).

Climate warming projections and their effect on benthic biodiversity were modeled with temperature scenarios $\left(-1^{\circ} \mathrm{C},+1^{\circ} \mathrm{C},+3^{\circ} \mathrm{C}\right)$ based on current SST trends (Muller-Karger et al. 2017) and 20-year forecast sea surface anomaly range for the study region (Chadwick et al. 2012). We used a linear relationship between SST and benthic assemblage diversity indices and composition (Shannon-weiner H', species richness, and \% Cover) as we had less than a year of monitoring. Climate projections were designed following: (1) description of the relationship between monthly biodiversity and SST variations through regression using current data to parameterize the models (input: monthly averages); (2) calculation of the expected monthly biodiversity based on the SST scenarios $\left(-1^{\circ} \mathrm{C},+1^{\circ} \mathrm{C},+3^{\circ} \mathrm{C}\right.$ added to the current monthly SST average) and the regression algorithms. Projected changes (average monthly changes, \%) were visually compared to the baseline information obtained in this study.

All statistical tests considered $\alpha=0.05$ significance level. Graphical and analytical processing was performed in ODV (Schlitzer, 2013), Panoply 4.8.1 (Schmunk, 2013), Numbers (Apple Inc.) and R project (R Development Core Team 2005) with packages: 'stats', 'GAD' (Sandrini-Neto and Camargo, 2014), 'vegan' (Oksanen et al., 2018), 'rich' (Rossi, 2016), 'outliers' (Komsta, 2011), and MASS (Ripley et al., 2019).

\section{Results}

\section{Meteo-oceanographic conditions}

Monthly meteo-oceanographic conditions changed markedly throughout the study (Fig. 1 and 2), with significant differences for air and sea temperatures, swell heights, and chlorophyll-a concentrations (ANOVA AirT F $=48.78$, SST F $=120.91$, SWH F $=268.6$, Chla F $=3.84$; $\mathrm{p}<$ 0.05 , Table 2). Air and sea temperatures ranged between 22 and $28^{\circ} \mathrm{C}$ and were correlated to each other $\left(r^{2}=0.92, p=0.0003\right.$; Supplement material Table S3), with maximum temperatures in the 
fall (Apr) and minima during winter (Aug) (Fig. 2, Supplement material Table S4). Precipitation and salinity averages varied from 44 to 36 and 30 to $37 \mathrm{ppm}$ respectively, and were not correlated $\left(\mathrm{df}=7, \mathrm{t}=0.64, \mathrm{r}^{2}=0.23, \mathrm{p}=0.5407\right)$. Significant wave heights varied from 1 to $1.5 \mathrm{~m}$, with higher heights at the beginning of summer (Dec) and during winter (May-Jun-Jul-Aug), and lower wave heights during fall (Mar) (Fig. 2, Supplement material Table S4). Average chlorophyll-a concentration varied from 1 to $4.5 \mathrm{mg} \mathrm{m}^{-3}$, being lower at the end of summer (Feb) to fall (Mar-Apr-May), higher in winter (Jun-Jul-Aug), and negatively related to sea temperatures (Fig. 2, Supplement material Table S3 and S4). Chlorophyll-a concentrations were higher at the northern sites (Coqueiral and Gramuté; Fig. 1), with an average difference of $0.7 \mathrm{mg}$ $\mathrm{m}^{-3}(\mathrm{~F}=8.11, \mathrm{p}=0.0118$; Table 1; Supplement material Table S5).

\section{Substrate rugosity and reef benthic cover}

The 3D imaging of the intertidal reefs indicated differences in substrate rugosity among the studied reefs $(F=14.34, p<0.001$; Table 2; Fig. 3). The northern reefs in Coqueiral and Gramute had higher rugosity when compared to Costa Bela and Enseada das Garças to the South $(\mathrm{p}<0.001$; Supplementary material Table S5).

Benthic assemblages at the lateritic reefs were dominated by macroalgae ( 58 taxa), with 26 Rhodophyta species, 15 Chlorophyta, and 17 Phaeophyta (Supplement material Table S6). Other taxa occurring on the reefs included cnidarians, bivalves, barnacles, hermit crabs, sea stars and urchins, gastropods, and sponges (Supplement material Table S6). The intertidal reefs were mostly covered with macroalgae (25 to 70\%) and cnidarians (Anthozoa: 12 to 26\%) (Fig. 4). Some species were sampled throughout the study at all sites, including encrusting calcareous algae, Ulva sp., Sargassum sp., and zoanthids (Fig. 4). Monthly trends in benthic assemblage composition were highly variable at each site with no clear seasonal pattern but we observed an overall higher taxa richness and diversity during fall (Fig. 3 and 4).

Benthic assemblages varied spatially in percent cover and species dominance (Fig. 3 and 4) ( site $F=87.6$ and $p=0.01$, Table 2 ). Between-site variability included differences in the live coverage (versus bare rock or sand; Fig. 4) as well as changes in the taxonomic dominance (Fig. 3). For instance, we observed a higher Rhodophyta species richness at Gramuté and Coqueiral, while Chlorophyta and Phaeophyta were more diverse at Gramuté and E. das Garças (Fig. 3). Within-taxon variability was lower in Anthozoa, which was mainly represented by Zoanthus sociatus and Palythoa tuberculosa. An exception was at Coqueiral reefs where corals were nearly absent (Fig. 3). Overall, taxa diversity was higher at Coqueiral $\left(\mathrm{H}^{\prime}=0.94\right)$ and Gramuté $\left(\mathrm{H}^{\prime}=\right.$ 0.88; $\mathrm{p}<0.01$; supplement material Table S7 and Fig. 4).

Benthic assemblage taxa composition also changed at temporal (monthly) scales ( $\mathrm{F}=$ 20.78, $\mathrm{p}=0.01$; Table 2) with significant variability in the fall (Apr-May) due to increased macroalgal coverage $(\mathrm{p}=0.028$, supplement material Table S8). Taxon diversity and richness were also higher during fall ( $p<0.05$, Table S8 and S9; Fig. 4), but monthly variations in species cover were similar across sites ( $p>0.05$, Supplement material Table S9). 


\section{Multivariate analysis}

Sea surface temperatures and substrate rugosity were significantly associated with benthic assemblage composition ( $\mathrm{p}<0.05$, Table 3, Fig. 5). The CAP ordination showed that benthic cover at Coqueiral and Gramuté were similar with higher contributions of turf, Sargassum sp., $P$. gymnosperma, D. marginata, and sediment/rock. The other two sites had higher contributions of anthozoans, which were positively related to sea surface temperature and rugosity (Fig. 5). Between-site differences could be distinguished by the set of variables pointed as significant by CAP, including sea surface temperature, benthic assemblage cover (Z. sociatus, P. tuberculosa, Sargassum sp., D. marginata, J. rubens, P. gymnosperma, Anthozoa, turf), and sediment/rock cover (Table 4). The precision of classification ranged from $56 \%$ to $88 \%$, being higher at Coqueiral and Gramuté. According to the discriminant coefficients, most variables were positively related to sea surface temperatures, with the exception of $P$. tuberculosa and $D$. marginata covers (Table 4).

The projected climatic scenarios changed the reef assemblage composition at multiple spatial scales (Fig. 6; Supplement material Table S10). Changes were expected on the taxa composition (\% cover from 1 to $100 \%$ ); also taxa diversity and richness $(0.2$ to $30 \%)$. Sites with lower substrate rugosity showed similar trends of assemblage change (positive or negative) for all taxa as well as for diversity and richness. Overall, reduced regional diversity (minus 13\% with $+1^{\circ} \mathrm{C}$ ) and Anthozoa cover (minus $43 \%$ with $+3^{\circ} \mathrm{C}$ ) were expected with increased temperature. At the local scale, forecasted higher temperatures reduced Anthozoa cover across multiple sites (minus $14 \%$ to $116 \%$ ). Positive effects on macroalgae and other invertebrate abundance are expected with increased temperatures, both regionally and at the sites. Macroalgae cover is expected to increase from $11\left(+1^{\circ} \mathrm{C}\right)$ to $32 \%\left(+3^{\circ} \mathrm{C}\right)$ regionally and up to $90 \%$ at the reefs with lower substrate rugosity (E. das Garças and Costa Bela). Other invertebrate abundances are projected to increase from 25 to $100 \%$ with warming. Reef assemblages (macroalgae and other invertebrates) are expected to be negatively affected by reduced temperatures, reducing species richness and diversity as well. In exception, lower temperatures are expected to increase Anthozoan cover $14 \%$ regionally and up to $100 \%$ at Coqueiral, site with highest surface rugosity.

\section{Discussion}

Ecosystem-based indicators are the foundations for modeling and forecasting ocean dynamics (Miloslavich, 2018). These approaches require biological data with a reasonable taxonomic resolution and algorithms that can accurately indicate biodiversity changes in response to environmental conditions. Our study reports a new baseline benthic biodiversity assessment of tropical intertidal lateritic reefs on the Eastern Brazil Marine Ecoregion that is under a decadal warming trend (Bernardino et al., 2015). The hypothesis that the composition and diversity of intertidal benthic assemblages would be associated with substrate rugosity and seasonal effects was validated, supporting the recognition of long-term monitoring of essential ocean variables on the South Atlantic (Muller-Karger et al. 2017; Mulbert et al., 2019).

Coastal intertidal reef benthic diversity was temporally correlated with sea surface temperatures. Variations of sea temperature are being increasingly recognized to change temporal 
362 patterns of coastal biodiversity at both seasonal and interannual time scales (Poloczanska et al., 363 2013, 2016). Our findings support that tropical marine intertidal reef ecosystems may be

364 extremely vulnerable to warming given the influence on benthic assemblage composition, especially on habitat-forming species such as anthozoans and macroalgae. Anthozoans should be the most negatively affected by higher temperatures, the major cause of bleaching, pathogen spread, and coral reef declines (Blackwood et al. 2017; Sully et al. 2019). On the other hand, years with negative temperature anomaly, observed within the warming trend, could benefit macroalgae and other invertebrates, such as sea urchins and decapods. Future benthic assemblage composition and states will depend on community feedbacks (Steneck \& Dethier, 1994; Duffy, 2002; Deáth et al., 2012; Lemieux \& Cusson, 2014; Andrades et al., 2019). Although temporal variability in benthic assemblage composition may be a matter of seasonality and turnover (Hartnoll \& Hawkins, 1980; Koehler \& Williams, 1996; Dye, 1998; Okuda et al., 2004), warming temperatures could negatively affect macroalgae beds and lead to decreased reef productivity and community shifts in the long term (Steneck \& Dethier, 1994; Sorte et al., 2017). Temperature effects were also observed to decrease larval diversity on the Eastern Brazil Marine Ecoregion (Mazzuco et al., 2019) and suggest that reduced overall benthic diversity on intertidal reefs may be associated to lower physiological fitness of both adult and larval life stages.

Spatial patterns of benthic assemblages were driven by differences in the coverage of macroalgae and anthozoans on intertidal reefs. The outcomes of macroalgae-anthozoa shifts to biodiversity and productivity vary across ecosystems (Norström et al. 2009; Chemello et al. 2018). Substrate rugosity is a major driver of benthic biodiversity on rocky shores (Guichard et al., 2001; Cruz-Mota et al., 2010; Bloch \& Klingbeil, 2016) and coral reefs (Zawada et al., 2010). We confirmed previous interactions of substrate rugosity and benthic species richness, diversity, and composition for intertidal lateritic reefs and their strong seasonal association with sea temperatures. Besides, regional differences in diversity were positively related to substrate rugosity and corroborate assertations of higher habitat availability at more complex reefs. These patterns indicate that not only should substrate rugosity to be considered and reported when analyzing coastal reef benthic assemblages, but also that sampling that occurred across sites of variable rugosity could result in misleading biogeographic patterns. spatial and temporal scales along these intertidal reefs. According to our findings, merging a specific set of in situ data (benthic cover of dominant taxa; i.e. Zoanthus sociatus, Paythoa tuberculosa, Padina gymnosperma, and others) and satellite remote sensing products (sea surface temperature) would allow meaningful long-term assessments of benthic biodiversity in tropical reefs at large scales, improving our capacity to manage these coastal ecosystems. Expanding the monitoring zone and frequency is a current challenge in this coast with the least amount of longterm ecological research sites. This framework simplifies reef monitoring protocols for the intertidal zone and may likely help management actions, for instance with early detection of biodiversity change. Our benthic assemblage database allows species tracking, change detection, and forecasting simulations for tropical lateritic reef communities. 
402

Generating high-resolution and long-term biodiversity information across marine ecosystems is urgent when dealing with environmental and climate emergencies (Canonico et al., 2019). This study not only provides a baseline open-access ecological database for the intertidal reefs in the Eastern Brazil Marine Ecoregion but also is the first attempt to project benthic biodiversity outcomes of warming for this region. The climate projections highlight a potential overall decrease in regional diversity of benthic assemblages with warming, corroborating global assessments of marine biodiversity loss (Scheffer et al. 2001) and the vulnerability of tropical reefs to climate change (IPCC 2019). It future community shifts in benthic diversity of lateritic reefs are confirmed, we should expect alterations in ecosystem trophic structure and negative impacts on ecosystem services at large scales.

\section{Conclusions}

Our results revealed a distinct benthic assemblage on intertidal lateritic reefs on the Eastern Brazil Marine Ecoregion, showing that substrate rugosity and seasonal changes temperature are key to taxa richness, diversity and species composition. Spatial patterns of assemblage structures were either dominated by macroalgae on more complex reefs, or Anthozoa, with reefs with lower rugosity indicating that habitat structure can have major influence on dominant taxa. The intimate association of temperature and species succession suggest that predicted warming in the Eastern Brazil Marine Ecoregion will have a major role in the loss of species and will change the species composition of intertidal reefs on the tropics, with yet unknown consequences to ecosystem process. Our work further illustrates the utility of monitoring tools based on in situ data and satellite remote sensing products, and support longterm global efforts to improve ecosystem management.

\section{Acknowledgments}

We thank all the co-workers from Grupo de Ecologia Bêntica for the assistance during field samplings and discussions. We would like to thank Lorena Monteiro for assisting in photoprocessing. We are also grateful to the Federal University of Espírito Santo and Instituto Chico Mendes for the support. This article is the \#006 contribution of The PELD (Long-term Program of Ecological Research) Coastal Habitats of Espírito Santo as part of the Brazilian LTER program.

\section{References}

Acker JG, Leptoukh G. 2007. Online analysis enhances use of NASA earth science data. EOS Transactions American Geophysical Union 88(2):14-17. DOI: 10.1029/2007EO020003 Albino J, Neto NC, Oliveira TCA. 2016. The Beaches of Espírito Santo. In: Short, A. D., Klein, A. H. F. (Eds), Brazilian beach systems. Springer, Sydney, pp. 333-361.

Anderson MJ. 2001. A new method for non-parametric multivariate analysis of variance. Austral Ecology 26:32-46. doi: 10.1111/j.1442-9993.2001.01070.pp.x 
442

Anderson MJ. 2006. Distance-based tests for homogeneity of multivariate dispersions. Biometrics 62:245-253. DOI: 10.1111/j.1541-0420.2005.00440.x

Anderson MJ. 2017. Permutational Multivariate Analysis of Variance (PERMANOVA). Wiley StatsRef: Statistics Reference Online,(C2014-2017 John Wiley \& Sons, Ltd. DOI: 10.1002/9781118445112.stat07841

Anderson MJ, Willis TJ. 2003. Canonical analysis of principal coordinates: a useful method of constrained ordination for ecology. Ecology 84:511-525. DOI: https://doi.org/10.1890/0012- 9658(2003)084[0511:CAOPCA]2.0.CO;2

Andrades R, Reis-Filho JA, Macieira RM, Giarrizzo T, Jean-Christophe J. 2018. Endemic fish species structuring oceanic intertidal reef assemblages. Scientific Reports 8:10791. DOI:10.1038/s41598-018-29088-0

Andrades R, Jackson A, Macieira RM, Reis-Filho JA, Bernardino AF, Joyeux J, Giarrizzo T. 2019. Niche-related processes in island intertidal communities inferred from stable isotopes data. Ecological Indicators 104:648-658. DOI: 10.1016/j.ecolind.2019.05.039

Anthony KRN, Kerswell AP 2007. Coral mortality following extreme low tides and high solar radiation. Marine Bioliology 151:1623-1631. DOI 10.1007/s00227-006-0573-0

Archambault P, Bourget E. 1996. Scales of coastal heterogeneity and benthic intertidal species richness, diversity and abundance. Marine Ecology Progress Series 136:111-121. DOI: 10.3354/meps 136111

Aued AW, Smith F, Quimbayo JP, Cândido DV, Longo GO, Ferreira CEL, Witman JD, Floeter SR, Segal B. 2018. Large-scale patterns of benthic marine communities in the Brazilian Province. PLoS ONE 13(6):e0198452. https://doi.org/10.1371/journal. pone.0198452 Azzarello JJ, Smale DA, Langlois TJ, Håkansson EJ. 2014. Linking habitat characteristics to abundance patterns of canopy-forming macroalgae and sea urchins in southwest Australia, Marine Biology Research 10(7):682-693. DOI: 10.1080/17451000.2013.841945

Bathiany S, Dakos V, Scheffer M, Lenton TM. 2018. Climate models predict increasing temperature variability in poor countries. Science Advances 4 (5):eaar5809. DOI: 10.1126/sciadv.aar5809

Bax NJ, Miloslavich P, Muller-Karger FE, Allain V, Appeltans W, Batten SD, Benedetti-Cecchi L, Buttigieg PL, Chiba S, Costa DP, Duffy JE, Dunn DC, Johnson CR, Kudela RM, Obura D, Rebelo L-M, Shin Y-J, Simmons SE and Tyack PL (2019) A Response to Scientific and Societal Needs for Marine Biological Observations. Frontiers in Marine Science 6:395. DOI: $10.3389 /$ fmars.2019.00395

Bellard C, Bertelsmeier C, Leadley P, Thuiller W, Courchamp F. 2012. Impacts of climate change on the future of biodiversity. Ecology Letters 15(4):365-377. DOI: 10.1111/j.14610248.2011.01736.x.

Bernardino AF, Netto SA, Pagliosa PR, Barros F, Christofoletti RA, Rosa Filho JS, Colling A, Lana PC. 2015. Predicting ecological changes on benthic estuarine assemblages through decadal climate trends along Brazilian Marine Ecoregions. Estuarine Coastal and Shelf Science 166:74-82. DOI: 10.1016/j.ecss.2015.05.021 
Bernardino AF, Pagliosa PR, Christofoletti RA, Barros F, Netto SA, Muniz P, Lana PC. 2016. Benthic estuarine communities in Brazil: moving forward to long term studies to assess climate change impacts. Brazilian Journal of Oceanography 64:83-97. DOI: 10.1590/S1679-875920160849064sp2

Bernhardt JR, Leslie HM 2013. Resilience to Climate Change in Coastal Marine Ecosystems. Annual Review in Marine Scince 5:371-92. DOI: 10.1146/annurev-marine-121211172411Blackwood JC, Okasaki C, Archer A, Marr E, Sherman E, Montovan K. 2017. Modeling alternative stable states in Caribbean coral reefs. Natural Resource Modeling, 31:e12157. DOI: $10.1111 / \mathrm{nrm} .12157$

Blanchette CA, Miner CM, Raimondi PT, Lohse D, Heady KEK, Broitman BR. 2008. Biogeographical patterns of rocky intertidal communities along the Pacific coast of North America. Journal of Biogeography 35:1593-1607. DOI: doi:10.1111/j.13652699.2008.01913.x

Bloch CP, Klingbeil BT. 2016. Anthropogenic factors and habitat complexity influence biodiversity but wave exposure drives species turnover of a subtropical rocky inter-tidal metacommunity. Marine Ecology 37:64-76. DOI: 10.1111/maec.12250

Burrows MT, Harvey R, Robb L. 2008. Wave exposure indices from digital coastlines and the prediction of rocky shore community structure. Marine Ecology Progress Series 353:1-12. DOI: https://doi.org/10.3354/meps07284

Carleton JH, Done T. 1995. Quantitative video sampling of coral reef benthos: large-scale application. Coral Reefs 14:35-46. DOI: 10.1007/BF00304070Canonico G, Buttigieg PL, Montes E, Muller-Karger FE, Stepien C, Wright D, Benson A, Helmuth B, Costello M, Sousa-Pinto I, Saeedi H, Newton J, Appeltans W, Bednaršek N, Bodrossy L, Best BD, Brandt A, Goodwin KD, Iken K, Marques AC, Miloslavich P, Ostrowski M, Turner W, Achterberg EP, Barry T, Defeo O, Bigatti G, Henry L-A, Ramiro-Sánchez B, Durán P, Morato T, Roberts JM, García-Alegre A, Cuadrado MS and Murton B. 2019. Global Observational Needs and Resources for Marine Biodiversity. Frontiers in Marine Science 6: 367. DOI: $10.3389 /$ fmars.2019.00367

Capotondi A, Jacox M, Bowler C, Kavanaugh M, Lehodey P, Barrie D, Brodie S, Chaffron S, Cheng W, Dias DF, Eveillard D, Guidi L, Iudicone D, Lovenduski N, Nye JA, Ortiz I, Pirhalla DE, Buil MP, Saba V, Sheridan SC, Siedlecki S, Subramanian A, Vargas C, Lorenzo E, Doney SC, Hermann AJ, Joyce T, Merrifield M, Miller AJ, Not F, Pesant S. 2019. Observational Needs Supporting Marine Ecosystems Modeling and Forecasting: Insights from U.S. Coastal Applications. Frontiers in Marine Science 6. doi: 10.3389/fmars.2019.00623

Chadwick R, Wu P, Good P, Andrews T 2013. Asymmetries in tropical rainfall and circulation patterns in idealised CO2 removal experiments. Climate Dynamics 40:295-316. DOI: 10.1007/s00382-012-1287-2

Chemello S, Vizzini S, Mazzola A. 2018. Regime shifts and alternative stable states in intertidal rocky habitats: State T of the art and new trends of research. Estuarine, Coastal and Shelf Science, 2014: 57-63. DOI: 10.1016/j.ecss.2018.09.013 
Cheung WWL, Lam VWY, Sarmiento JL, Kearney K, Watson R, Pauly D. 2009. Projecting global marine biodiversity impacts under climate change scenarios. Fish and Fisheries 10:235-251. DOI: 10.1111/j.1467-2979.2008.00315.x

Coutinho R, Yaginuma LE, Siviero F, Santos JCPQ, López MS, Christofoletti RA, Berchez F, Ghilardi-Lopes NP, Ferreira CEL, Gonçalves JEA, Masi BP, Correia MD, Sovierzoski HH, Skinner LF, Zalmon IR. 2016. Coutinho Studies on benthic communities of rocky shores on the Brazilian coast and climate change monitoring: status of knowledge and challenges. Brazilian Journal of Oceanography 64(2):27-36. DOI: 10.1590/S1679875920161015064 sp2

Cruz-Motta JJ, Miloslavich P, Palomo G, Iken K, Konar B, Pohle G, Trott T, Benedetti-Cecchi L, Herrera C, Hernández A, Sardi A, Bueno A, Castillo J, Klein E, Guerra-Castro E, Gobin J, Gómez DI, Riosmena-Rodríguez R, Mead A, Bigatti G, Knowlton A, Shirayama Y. 2010. PLoS One 5(12): e14354. DOI: 10.1371/journal.pone.0014354.

De'ath G, Fabricius KE, Sweatman H, Puotinen M. 2012. The 27-year decline of coral cover on the Great Barrier Reef and its causes. PNAS 109(44):17995-17999. DOI: 10.1073/pnas.1208909109

Dias GM, Christofoletti RA, Kitazawa K, Jenkins SR. 2018. Environmental heterogeneity at small spatial scales affects population and $\mathrm{T}$ community dynamics on intertidal rocky shores of a threatened bay system. Ocean and Coastal Management 164:52-59. DOI: 10.1016/j.ocecoaman.2017.12.001

Duffy JE. 2002. Biodiversity and ecosystem function: the consumer connection. Oikos 99:201219. DOI: 10.1034/j.1600-0706.2002.990201.x

Dulvy NK, Sadovy Y, Reynolds JD. 2003. Extinction vulnerability in marine populations. Fish and Fisheries 4:25-64. DOI: 10.1046/j.1467-2979.2003.00105.x

Dye AH. 1998. Community-level analyses of long-term changes in rocky littoral fauna from South Africa. Marine Ecology Progress Series 164:47-57 DOI: 10.3354/meps164047

Ferreira CEL, Gonçalves JEA, Coutinho R. 2001. Community structure of fishes and habitat complexity on a tropical rocky shore. Environmental Biology of Fishes 61:353-369. DOI: 10.1023/A:1011609617330

Fuchs T (2013). Effects of habitat complexity on invertebrate biodiversity. Immediate Science Ecology 2: 1-10. DOI: 10.7332/ise2013.2.1.dsc

Gotelli NJ, Ellison AM. 2004. A primer of ecological statistics. Sunderland: Sinauer Associates. Griffiths JR, Kadin M, Nascimento FJA, Tamelander T, Törnroos A, Bonaglia S, Bonsdorff E, Brüchert V, Gårdmark A, Järnström M, Kotta J, Lindegren M, Nordström MC, Norkko A, Olsson J, Weigel B, Žydelis R, Blenckner T, Niiranen S, Winder M. 2017. The importance of benthic-pelagic coupling for marine ecosystem functioning in a changing world. Global Change Biology 23(6):2179-2196. DOI: 10.1111/gcb.13642

Guidetti P, Bianchi CN, Chiantore M, Schiaparelli S, Morri C, Cattaneo-Vietti R. 2004. Living on the rocks: substrate mineralogy and the structure of subtidal rocky substrate communities in 
the Mediterranean Sea. Marine Ecology Progress Series 274:57-68. DOI: 10.3354/meps 274057

Guichard F, Bourget E, Robert JL 2001. Scaling the influence of topography heterogeneity on intertidal benthic communities: alternate trajectories mediated by hidrodinamics and shading. Marine Ecology Progress Series 217:27-41. DOI: 10.3354/meps217027

Halpern BS, Walbridge S, Selkoe KA, Kappel CV, Micheli F, D’Agrosa C, Bruno JF, Casey KS, Ebert C, Fox HE, Fujita R, Heinemann D, Lenihan HS, Madin EMP, Perry MT, Selig ER, Spalding M, Steneck R, Watson R. 2008. A Global Map of Human Impact on Marine Ecosystems. Science 319 (5865):948-952. DOI: 10.1126/science.1149345

Harley CDG 2011. Climate change, keystone predation, and biodiversity loss. Science 334, 1124-1127. DOI: 10.1126/science. 1210199

Harnik PG, Lotze HK, Anderson SC, Finkel ZV, Finnegan S, Lindberg DR, Liow LH, Lockwood R, McClain CR, McGuire JL, O’Dea A, Pandolfi JM, Simpson C, Tittensor DP. 2012. Extinctions in ancient and modern seas. Trends in Ecology and Evolution 27(11):608-617. DOI: $10.1016 /$ j.tree.2012.07.010

Hartnoll RG, Hawkins SJ. 1980. Monitoring rocky-shore communities: a critical look at spatial and temporal variation. Helgolinder Meeresunters 33:484-494. https://doi.org/10.1007/BF02414773

Hiscock K, Southward A, Tittley I, Hawkins S (2004). Effects of changing temperature on benthic marine life in Britain and Ireland. Aquatic Conservation: Marine Freshwater Ecosystems 14:333-362. DOI: 10.1002/aqc.628

Huntington BE, Karnauskas M, Babcock EA, Lirman D (2010) Untangling Natural Seascape Variation from Marine Reserve Effects Using a Landscape Approach. PLoS ONE 5(8):e12327. DOI:10.1371/journal.pone.0012327

IPCC, 2019: Summary for Policymakers. In: IPCC Special Report on the Ocean and Cryosphere in a Changing Climate [H.-O. Pörtner, D.C. Roberts, V. Masson-Delmotte, P. Zhai, M. Tignor, E. Poloczanska, K. Mintenbeck, M. Nicolai, A. Okem, J. Petzold, B. Rama, N. Weyer (eds.)]. In press.

Jacquette E, Bitar A, Mialon A, Kerr YH, Quesney A, Cabot F, Richaume PH. 2010. "SMOS CATDS level 3 global products over land “, proceeding SPIE, sept. 2010, Toulouse. Johnson MP, Frost NJ, Mosley WJ, Roberts MF, Hawkins SJ. The area-independent effects of habitat complexity on biodiversity vary between regions. Ecology Letters 6:126-132. DOI: https://doi.org/10.1046/j.1461-0248.2003.00404.x

Jueterbock A, Tyberghein L, Verbruggen H, Coyer JA, Olsen JL, Hoarau G. 2013. Climate change impact on seaweed meadow distribution in the North Atlantic rocky intertidal. Ecology and Evolution 3(5):1356-1373. DOI: 10.1002/ece3.541

Kalnay E, Kanamitsu M, Kistler R, Collins W, Deaven D, Gandin L, Iredell M, Saha S, White G, Woollen J, Zhu Y, Leetmaa A, Reynolds B, Chelliah M, Ebisuzaki W, Higgins W, Janowiak J, Mo KC, Ropelewski C, Wang J, Jenne R, Joseph D. 1996. The NCEP/NCAR 40-year reanalysis project. Bulletin of the American Meteorolical Society 77: 437- 472. DOI: 10.1175/1520-0477(1996)077<0437:TNYRP $>2.0$. CO;2 
604

605

606

607

608

609

610

611

612

613

614

615

616

617

618

619

620

621

622

623

624

625

626

627

628

629

630

631

632

633

634

635

636

637

638

639

640

641

642

Kelmo F, Bell JJ, Moraes SS, Gomes RdCT, Mariano-Neto E, Attrill MJ. 2014. Differential Responses of Emergent Intertidal Coral Reef Fauna to a Large-Scale El-Nin o Southern Oscillation Event: Sponge and Coral Resilience. PLoS ONE 9(3): e93209. doi:10.1371/journal.pone.0093209

Komsta L. 2011. Outliers: Tests for Outliers. R package version 0.14, URL http://CRAN. Rproject.org/.

Kordas RL, Dudgeon S, Storey S, Harley CDG 2015. Intertidal community responses to fieldbased experimental warming. Oikos 124:888-898, 2015. DOI: 10.1111/oik.00806

Kovalenco KE, Thomaz SM, Warfe DM. 2012. Habitat complexity: approaches and future directions. Hydrobiologia 685: 1-17. DOI: 10.1007/s10750-011-0974-z

Lamy T, Reed DC, Rassweiler A, Siegel DA, Kui L, Bell TW, Simons RD, Miller RJ. 2018. Scale-specific drivers of kelp forest communities. Oecologia 186:217-233 https://doi.org/10.1007/s00442-017-3994-1

Leclerc J-C 2018. Patterns of spatial variability between contrasting substrata: a boulder-field study. Marine Ecology Progress Series 597: 23-38. DOI: 10.3354/meps12585

Lemieux J, Cusson M. 2014. Effects of Habitat-Forming Species Richness, Evenness, Identity, and Abundance on Benthic Intertidal Community Establishment and Productivity. PLoS ONE 9(10):e109261. DOI:10.1371/journal.pone.0109261

Lenth RV. 2001. Some practical guidelines for effective sample size determination. The American Statistician 55:187-193. DOI: 10.1198/000313001317098149

Londoño-Cruz E, Mesa-Agudelo LAL, Arias-Galvez F, Herrera-Paz DL, Prado A, Cuellar LM, Cantera J 2014. Distribution of macroinvertebrates on intertidal rocky shores in Gorgona Island, Colombia (Tropical Eastern Pacific). Revista de Biología Tropical 62 (1):189-198.

Longo GO, Hay ME, Ferreira CEL, Floeter SR 2018. Trophic interactions across 61 degrees of latitude in the Western Atlantic. Global Ecology and Biogeography 28:107-117. DOI: $10.1111 /$ geb.12806

MASSS 2019. Support Functions and Datasets for Venables and Ripley's MASS. R package version 7.3-51.4, https://cran.r-project.org/web/packages/MASS/MASS.html

Mazzuco ACA, Stelzer PS, Donadia G, Bernardino JV, Joyeux J, Bernardino AF. 2019. Lower diversity of recruits in coastal reef assemblages are associated with higher sea temperatures in the tropical South Atlantic. Marine Environmental Research 148:87-98.

DOI:10.1016/j.marenvres.2019.05.008

McArdle BH, Anderson MJ. 2001. Fitting Multivariate Models to Community Data: A Comment on Distance-Based Redundancy Analysis. Ecology 82:290-297. DOI: 10.1890/00129658(2001)082[0290:FMMTCD]2.0.CO;2

McArthur MA, Brooke BP, Prezeslawski R, Ryan DA, Lucieer VL, Nichol S, McCallum AW, Mellin C, Cresswell ID, Radke LC. 2010. On the use of abiotic surrogates to describe marine benthic biodiversity. Estuarine, Coastal and Shelf Science 88:21e32. DOI: 10.1016/j.ecss.2010.03.003

Peer] reviewing PDF | (2019:07:39107:3:0:CHECK 14 Nov 2019) 
643

644

645

646

647

648

649

650

651

652

653

654

655

656

657

658

659

660

661

662

663

664

665

666

667

668

669

670

671

672

673

674

675

676

677

678

679

680

681

682

McCauley DJ, Pinsky ML, Palumbi SR, Estes JA, Joyce FH, Warner RR. 2018. Marine defaunation: Animal loss in the global ocean. Science 347:1255641. DOI: 10.1126/science. 1255641

McIntyre AD. 2010. Life in the World's Oceans: Diversity, Distribution and Abundance. WileyBlackwell.

Meadows AS, Ingels J, Widdicombe S, Hale R, Rundle SD. 2015. Effects of elevated CO2 and temperature on an intertidal meiobenthic community. Journal of Experimental Marine Biology and Ecology 469:44-56.

Meager JJ, Schalacher TA, Green M 2011. Topographic complexity and landscape temperature patterns create a dynamic habitat structure on a rocky intertidal shore. Marine Ecology Progress Series 428:1-12. DOI: doi: 10.3354/meps09124

Meager JJ, Schlacher T. 2013. New metric of microhabitat complexity predicts species richness on a rocky shore. Marine Ecology 34:484-491.

Meißner K, Fiorentino D, Schnurr S, Arbizu PM, Huettmann F, Holst S, Brix S, Svavarsson J. 2014. Distribution of benthic marine invertebrates at northern latitudes - An evaluation applying multi-algorithm species distribution models. Journal of Sea Research 85:241-254. DOI: http://dx.doi.org/10.1016/j.seares.2013.05.007

Menge BA, Daley BA, Wheeler PA, Dahlhoff E, Sanford E, Strub PT. 1997. Benthic-pelagic links and rocky intertidal communities: Bottom-up effects on top-down control? Proceedings of the National Academy of Science (94):14530 -14535. DOI: 10.1073/pnas.94.26.14530

Menge BA, Lubchenco J, Bracken MES, Chan F, Foley MM, Freidenburg TL, Gaines SD, Hudson G, Krenz C, Leslie H, Menge DNL, Russell R, Webster MS. 2003. Coastal oceanography sets the pace of rocky intertidal community dynamics. Proceedings of the National Academy of Science 100(21):12229-12234. DOI: 10.1073pnas. 1534875100

Miloslavich P, Seeyave S, Muller-Karger F, Bax N, Ali E, Delgado C, Evers-King H, Loveday B, Lutz V, Newton J, Nolan G, Brichtova ACP, Traeger-Chatterjee C, Urban E. 2018. Challenges for global ocean observation: the need for increased human capacity. Journal of Operational Oceanography, DOI: 10.1080/1755876X.2018.1526463

Morelissen B, Harley CDG 2007. The effects of temperature on producers, consumers, and plantherbivore interactions in an intertidal community. Journal of Experimental Marine Biology and Ecology, 348:162-173. doi:10.1016/j.jembe.2007.04.006

Muelbert JH, Nidzieko NJ, Acosta ATR, Beaulieu S, Bernardino AF, Boikova E, Bornman TG, Cataletto B, Deneudt K, Eliason E, Kraberg A, Nakaoka M, Pugnetti1 A, Ragueneau O, Scharfe M, Soltwedel T, Sosik HM, Stanisci A, Stefanova K, Stéphan P, Stier A, Wikner J, Zingone A. 2019. ILTER-the International long-term ecological research network as a platform for global coastal and ocean observation. Frontiers in Marine Science 6:527. DOI:10.3389/fmars.2019.00527

Muller-Karger F, Piola A, Verheye HM, O’Brien TD, Lorenzoni L. 2017. Chapter 5: South Atlantic Ocean. In: What are Marine Ecological Time Series telling us about the ocean? A 
683

684

685

686

687

688

689

690

691

692

693

694

695

696

697

698

699

700

701

702

703

704

705

706

status report. Edition: IOC/2017/TS129. Publisher: IOC-UNESCO. Editors: T. D. O'Brien, L. Lorenzoni, K. Isensee, L. Valdés

Navarrete SA, Wieters EA, Broitman BR, Castilla JC. 2005. Scales of benthic-pelagic coupling and the intensity of species interactions: From recruitment limitation to top-down control. Proceedings of the National Academy of Science 102(50):18046-18051. DOI: 10.1073 pnas.0509119102

Norström AV, Myström M, Lokrantz J, Folke C 2009. Alternative states on coral reefs: beyond coral-macroalgal phase shifts. Marine Ecology Progress Series, 376: 295-306 DOI: $10.3354 /$ meps 07815

O'Hara TD. 2001. Consistency of faunal and floral assemblages within temperate subtidal rocky reef habitats. Marine and Freshwater Research 52:853-63. DOI: 10.1071/MF00114

Oksanen J, Blanchet FG, Kindt R, Legendre P. 2018. vegan: community ecology package. R package version 20-10, https://cran.r-project.org/web/packages/ vegan/index.html

Okuda T, Noda T, Yamamoto T, Ito N, Nakaoka M. 2004. Latitudinal gradient of species diversity: multi-scale variability in rocky intertidal sessile assemblages along the Northwestern Pacific coast. Population Ecology (2004) 46:159-170. DOI 10.1007/s10144004-0185-9

Olabarria C, Arenas F, Viejo RM, Gestoso I, Vaz-Pinto F, Incera M, Rubal M, Cacabelos E, Veiga P, Sobrino C. 2013. Response of macroalgal assemblages from rockpools to climate change: effects of persistent increase in temperature and CO2. Oikos 122:1065-1079. DOI: 10.1111/j.1600-0706.2012.20825.x

Palumbi S, Evans T, Pespeni MH, Somero G. 2019. Present and Future Adaptation of Marine Species Assemblages: DNA-Based Insights into Climate Change from Studies of Physiology, Genomics, and Evolution. Oceanography 32(3):82-93. DOI: 10.5670/oceanog.2019.314

Pereira AF, Belém AL, Castro BM, Geremias RG. 2005. Tide-topography interaction along the eastern Brazilian shelf. Continental Shelf Research 25:1521-1539. doi:10.1016/j.csr.2005.04.008

Piacenza SE, Barner AK, Benkwitt CE, Boersma KS, Cerny-Chipman EB, Ingeman KE, Kindinger TL, Lee JD, Lindsley AJ, Reimer JN, Rowe JC, Shen C, Thompson KA, Thurman LL, Heppell SS. 2015. Patterns and variation in benthic biodiversity in a large marine ecosystem. PLoS ONE 10(8): e0135135. DOI:10.1371/journal.pone.0135135

Pianca C, Mazzini PLF, Siegle E. 2010. Brazilian offshore wave cli- mate based on NWW3 reanalysis. Brazilian Journal of Oceanography 58(1):53-70. doi:10.1590/S167987592010000100006

Pineda J, López M. 2002. Temperature, stratification and barnacle larval settlement in two Californian sites. Continental Shelf Research 22:1183-1198. doi:10.1016/S02784343(01)00098-X

Poloczanska ES, Brown CJ, Sydeman WJ, Kiessling W, Schoeman DS, Moore PJ, Brander K., Bruno JF, Buckley LB, Burrows MT, Duarte CM, Halpern BS, Holding J, Kappel CV, O’Connor MI, Pandolfi JM, Parmesan C, Schwing F, Thompson S, Richardson AJ. 2013. 
724

725

726

727

728

729

730

731

732

733

734

735

736

737

738

739

740

741

742

743

744

745

746

747

748

749

750

751

752

753

754

755

756

757

758

759

760

761

762

763

764

Global imprint of climate change on marine life. Nature Climate Change 3:919-925. DOI:10.1038/NCLIMATE1958

Poloczanska ES, Burrows MT, Brown CJ, Molinos JG, Halpern BS, Hoegh-Guldberg O, Kappel CV, Moore PJ, Richardson AJ, Schoeman DS, Sydeman WJ. 2016. Responses of Marine Organisms to Climate Change across Oceans. Frontiers in Marine Science 3:1-21. DOI: 10.3389/fmars.2016.00062

Price DM, Robert K, Callaway A, Lolacono C, Hall RA, Huvenne VAE. 2019. Using 3D photogrammetry from ROV video to quantify coldwater coral reef structural complexity and investigate its influence on biodiversity and community assemblage. Coral Reefs. DOI: 10.1007/s00338-019-01827-3

Puente A, Guinda X, Juanes, JA, Ramos E, Echavarri-Erasun B, Hoz CF, Degraer S, Kerckhof F, Bojanic N, Rousou M, Orav-kotta H, Kotta J, Jourde J, Pedrotti ML, Leclerc J, Simon N, Bachelet G, Lavesque N, Arvanitidis C, Pavloudi C, Faulwetter S, Crowe TP, Coughlan J, Benedetti-Cecchi L, dal bello M, Magni P, Como S, Coppa S, de Lucia GA, Rugins T, Jankowska E, Weslawski JM, Warzocha J, Silva T, Ribeiro P, de Matos V, Sousa-Pinto I, Troncoso J, Peleg O, Rilov G, Espinosa F, Ruzafa AP, Frost M, Hummel H, van Avesaath P. 2017. The role of physical variables in biodiversity patterns of intertidal macroalgae along European coasts. Journal of the Marine Biological Association of the United Kingdom 97(3): 549-560. DOI:10.1017/S0025315416001673

Reynolds RW, Smith TM, Liu C, Chelton DB, Casey K, Schlax MG. 2007. Daily high-resolutionblended analyses for sea surface temperature. Journal of Climate 20:5473-5496. doi:10.1175/2007J CLI1824.1

Rossi J. 2016. Rich: Computes and Compares Species Richnesses. R package version 1.0.1, URL http://CRAN. R-project.org/.

Sandrini-Neto L, Camargo M. 2014. GAD: an R package for ANOVA designs from general principles. Available on CRAN.

Santamaría L, Méndez PF. 2012. Evolution in biodiversity policy - current gaps and future needs. Evolutionary Applications 5(2):202-218. DOI: 10.1111/j.1752-4571.2011.00229.x

Scheffer M, Carpenter S, Foley JA, Folke C, Walker B. 2001. Catastrophic shifts in ecosystems. Nature 413:591-596. DOI:

Scherner F, Horta PA, Oliveira EC, Simonassi JC, Hall-Spencer JM, Chow FC, Nunes JMC, Pereira SMB. 2013. Coastal urbanization leads to remarkable seaweed species loss and community shifts along the SW Atlantic. Marine Pollution Bulletin 76:106-115. DOI: 10.1016/j.marpolbul.2013.09.019

Schlitzer R. 2013. Ocean data view. http://odv.awi.de

Schmunk RB. 2013. Panoply 3.2.1. http://www.giss.nasa.gov/tools/panoply/

Smit K, Glassom D. 2017. Large fluctuations but constant mean temperatures allow corals to persist in intertidal rock pools on the east coast of South Africa. Helgoland Marine Researd 71:3. DOI: $10.1186 / \mathrm{s} 10152-017-0482-2$ 
765

766

767

768

769

770

771

772

773

774

775

776

777

778

779

780

781

782

783

784

785

786

787

788

789

790

791

792

793

794

795

796

797

798

799

800

801

802

803

Smith JR, Fong P, Ambrose R. 2006. Dramatic declines in mussel bed community diversity: response to climate change. Ecology 87(5):1153-1161. DOI: 10.1890/00129658(2006)87[1153:DDIMBC]2.0.CO;2

Sokal R, Rohlf FJ. 2003. Biometry: the principles and practice of statistics in biological research. WH Freeman and Company, New York.

Solan M, Cardinale BJ, Downing AL, Engelhardt KAM, Ruesink JL, Srivastava DS. 2004. Extinction and Ecosystem Function in the Marine Benthos. Science 306 (5699):1177-1180. DOI: 10.1126/science. 1103960

Sorte CJB, Davidson VE, Franklin MC, Benes KM, Doellman MM, Etter RJ, Hannigan RE, Lubchenco J, Menge BA. 2017. Long-term declines in an intertidal foundation species parallel shifts in community composition. Global Change Biology 23:341-352. DOI: $10.1111 /$ gcb. 13425

Starko S, Bailey LA, Creviston E, James KA, Warren A, Brophy MK, Danasel A, Fass MP, Townsend JA, Neufeld CJ. 2019. Environmental heterogeneity mediates scale- dependent declines in kelp diversity on intertidal rocky shores. PLoS ONE 14(3): e0213191. DOI: 10.1371/journal.pone.0213191

Steneck RS, Dethier MN. 1994. A Functional Group Approach to the Structure of AlgalDominated Communities. Oikos 69(3):476-498. DOI: 10.2307/3545860

Sully S, Burkepile DE, Donovan MK, Hodgson G, van Woesik R. 2019. A global analysis of coral bleaching over the past two decades. Nature Communications. DOI: 10.1038/s41467019-09238-2

Sunday J, Bennett JM, Calosi P, Clusella-Trullas S, Gravel S, Hargreaves AL, Leiva FP, Verberk WCEP, Olalla-Tárraga MA, Morales-Castilla I. 2019. Thermal tolerance patterns across latitude and elevation. Philosophical Transactions of the Royal Society B: Biological Sciences 374:20190036. DOI: 10.1098/rstb.2019.0036

Timpane-Padgham BL, Beechie T, Klinger T (2017) A systematic review of ecological attributes that confer resilience to climate change in environmental restoration. PLoS ONE 12(3): e0173812. DOI: 10.1371/journal.pone.0173812

Thompson RC, Crowe TP, Hawkins SJ (2002). Rocky intertidal communities: past environmental changes, present status and predictions for the next 25 years. Environmental Conservation 29 (2):168-191. DOI: DOI:10.1017/S0376892902000115

Tukey J. 1949. Comparing individual means in the analysis of variance. Biometrics 5 (2):99-114. DOI: $10.2307 / 3001913$.

Underwood AJ. 1997. Experiments in ecology. Their logical design and interpretation using analysis of variance. Cambridge University Press, Cambridge.

Vafeiadou A-M, Lloyd B, Bretaña P, Colen CV, Santos GAP, Moens T. 2018. Global warminginduced temperature effects to intertidal tropical and $\mathrm{T}$ temperate meiobenthic communities. Marine Environmental Research 142:163-177. DOI:

10.1016/j.marenvres.2018.10.005

Peer] reviewing PDF | (2019:07:39107:3:0:CHECK 14 Nov 2019) 
804 Valdivia N, Gonza' lez AE, Manzur T, Broitman BR (2013) Mesoscale variation of mechanisms 805 contributing to stability in rocky shore communities. PLoS ONE 8(1):e54159.

806 DOI:10.1371/journal.pone.0054159

807

808

809

810

811

812

813

814

815

816

817

818

819

820

821
Williams SM, Chollett I, Roff G, Cortés J, Dryden CS, Mumby PJ (2015). Hierarchical spatial patterns in Caribbean reef benthic assemblages. Journal of Biogeography 42 1327-1335. DOI: $10.1111 /$ jbi.12509

Wallingford PD, Sorte CJB. 2019. Community regulation models as a framework for direct and indirect effects of climate change on species distributions. Ecosphere 10(7):e02790. DOI: $10.1002 /$ ecs 2.2790

Wethey DS, Woodin SA, Hilbish TJ, Jones SJ, Lima FP, Brannock PM. 2011. Response of intertidal populations to climate: Effects of extreme events versus long term change. Journal of Experimental Marine Biology and Ecology 400: 132-144. DOI: 10.1016/j.jembe.2011.02.008

Young GC, Dey S, Rogers AD, Exton D. 2017. Cost and time-effective method for multi-scale measures of rugosity, fractal dimension, and vector dispersion from coral reef 3D models. PLoS ONE 12(4):e0175341. DOI: 10.1371/journal.pone.0175341

Zawada DG, Piniak GA, Hearn C. 2010. Topographic complexity and roughness of a tropical seascape. Geophysical Research Letters, 37: LI4604. DOI: 10.1029/2010GL043789 
Figure 1

Study area.

Location of the study area (APA Costa das Algas) and the four study sites in the Eastern coast of Brazil. Monthly variations in sea surface chlorophyll-a concentrations [mg $\mathrm{m}^{-3}$ ] during the study (December 2017 to August 2018) at each site, Coqueiral (A), Gramuté (B), Enseada das Garças (C), and Costa Bela (D). Note: symbols and error bars represent local (site) averages per month and standard deviations, respectively.

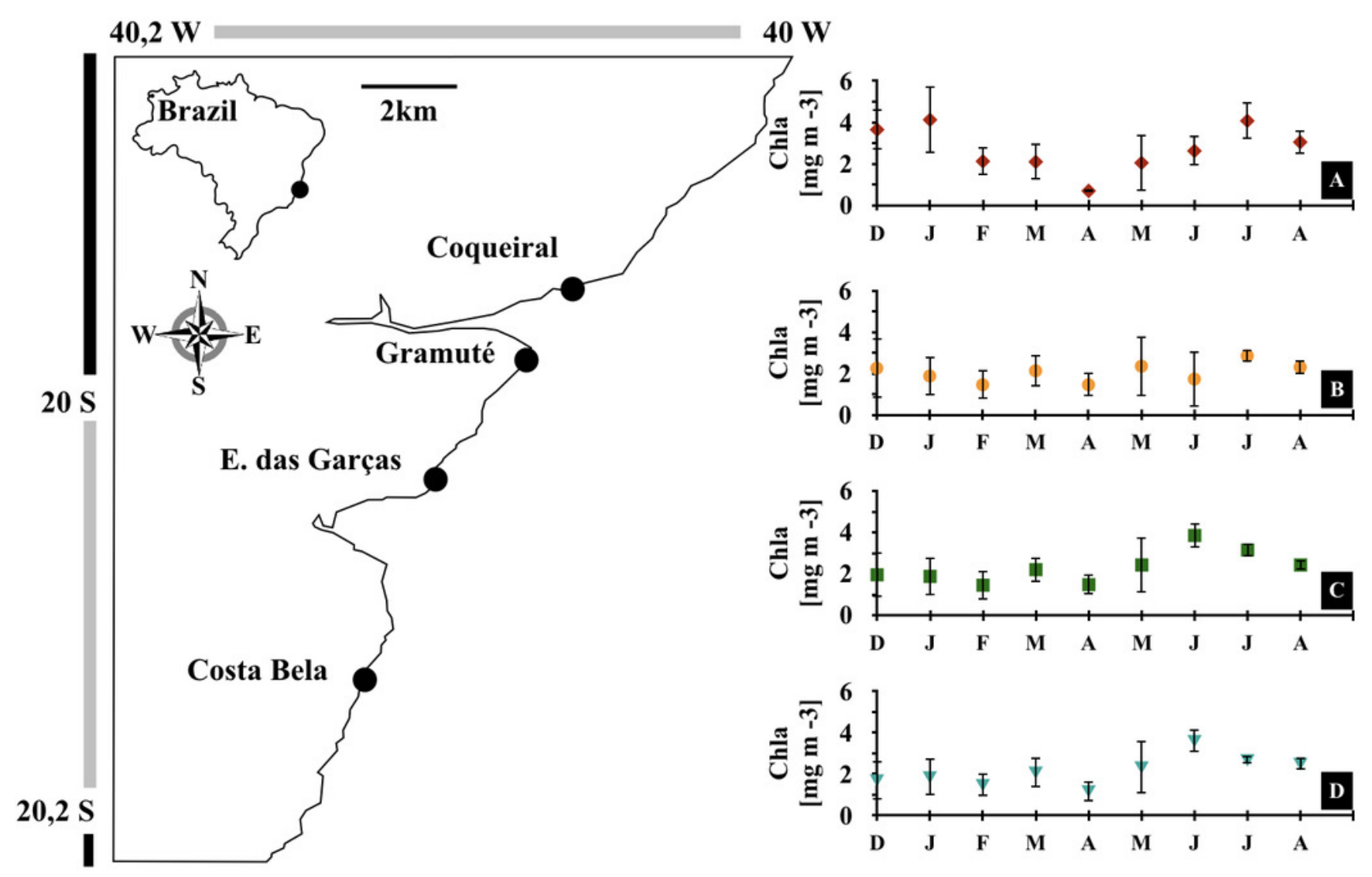


Figure 2

Meteo-oceanographic conditions.

Meteo-oceanographic conditions monitored during the study. Air and sea surface temperatures (Temp., AirT, SST; A, B), chlorophyll-a concentrations (Chla; C), precipitable water (Precip. D), salinity (E), and significant wave height (SWH) (F). Note: symbols and error bars represent regional $(4-30 \mathrm{~km})$ averages per month and standard deviations, respectively. 

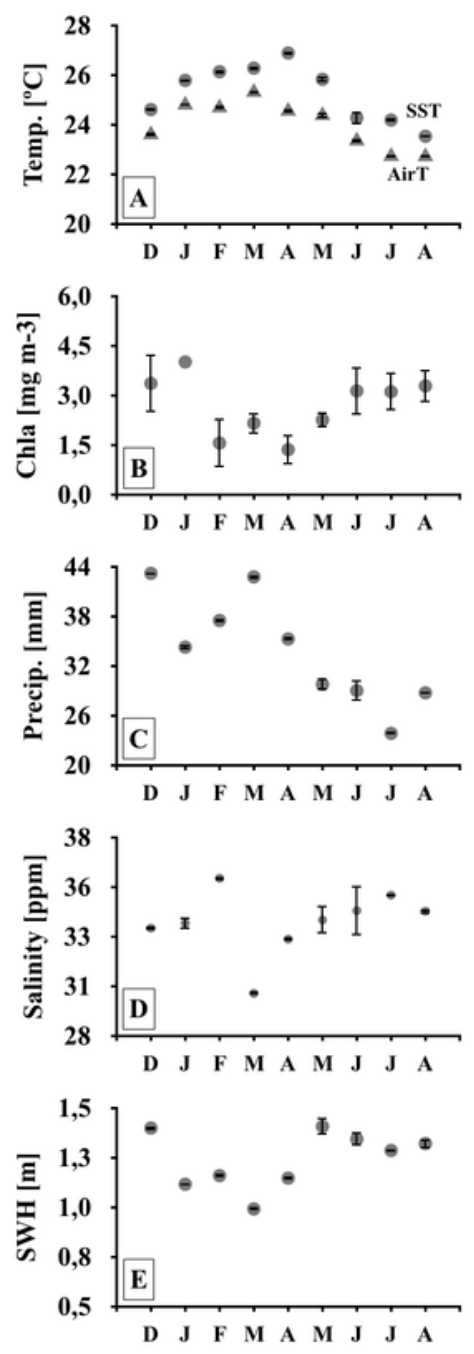


\section{Figure 3}

3D imaging of the intertidal reefs and benthic assemblages.

3D imaging of the intertidal reefs and taxonomic composition of the benthic assemblages at Coqueiral (A-B), Gramuté (C-D), Enseada das Garças (E-F), and Costa Bela (G-H). Note: surface contours are represented in a natural color and species diversity is highlighted with color gradients. ND stands for no data available. 


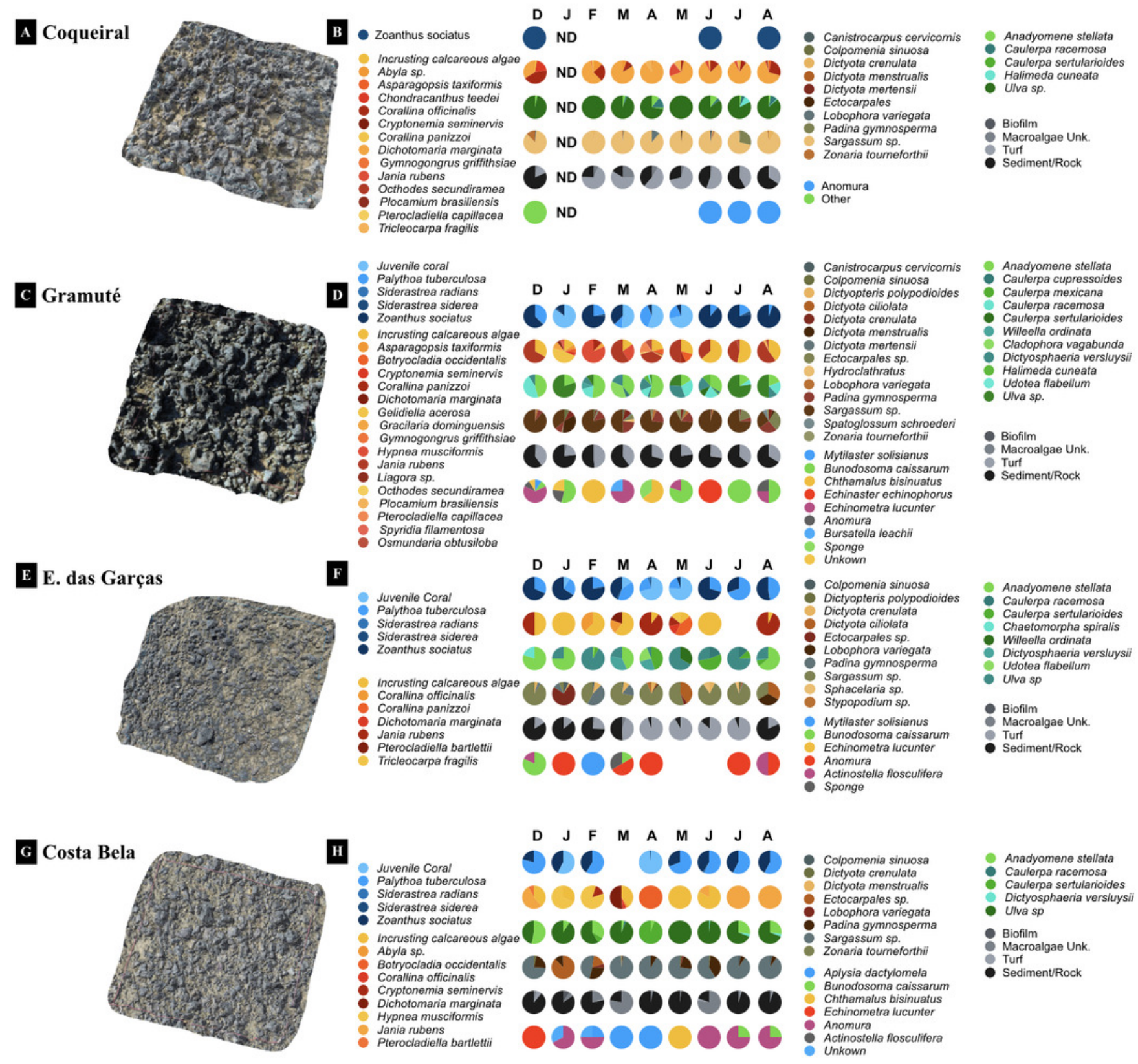


Figure 4

Spatio-temporal variations in the reef benthic biodiversity.

Monthly diversity (A, C, E, G) ( $H^{\prime}$, Shannon-Wiener Index S-W), richness (A, C, E, G) (number of species/taxon per quadrat per month), and assemblage composition (B, D, F, H) (variation in \% cover) at the study sites. Note: averages and standard deviations are represented by columns and error bars respectively; color bars represent relative cover per taxa plus sediment and rock. ND stands for no data available.

A Coqueiral

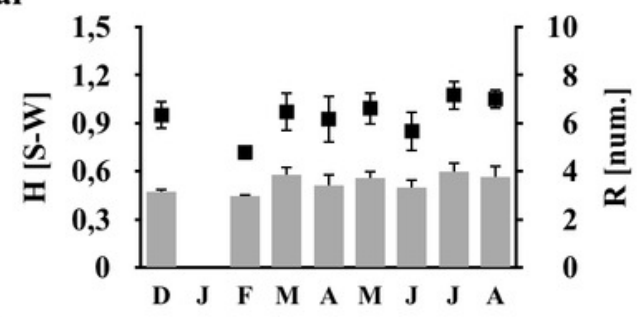

C Gramuté

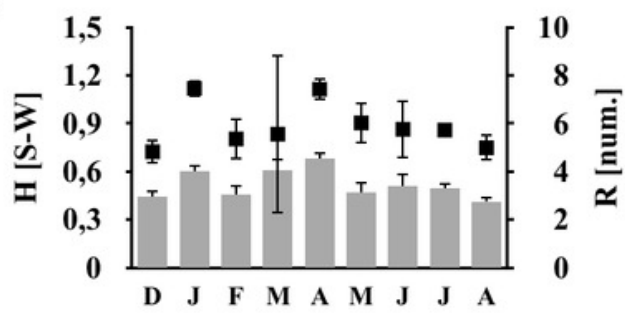

E E. das Garças

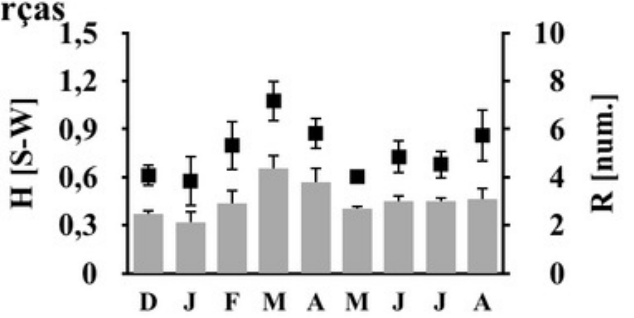

G Costa Bela

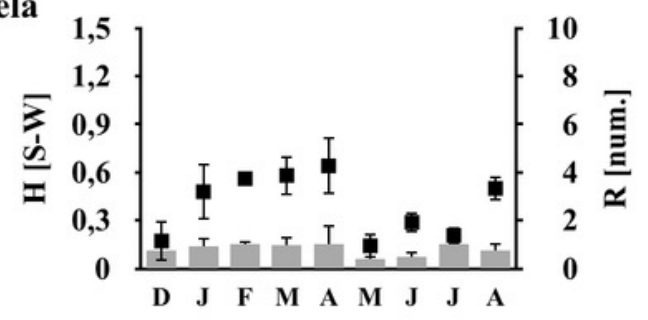

B

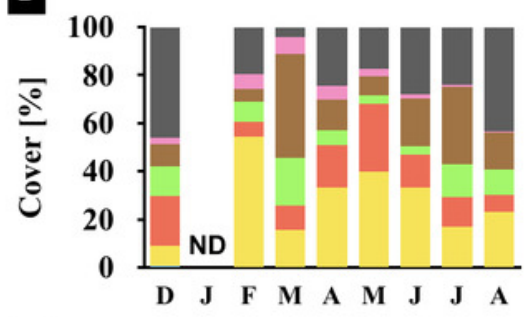

D

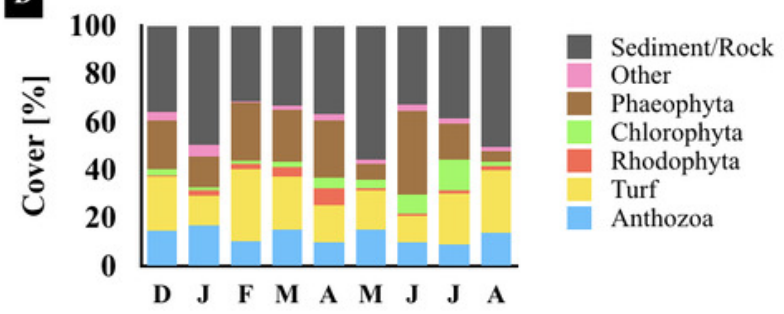

F

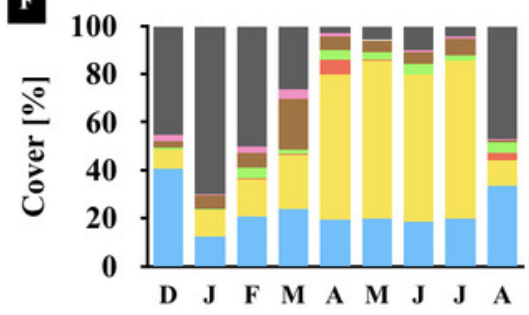

H

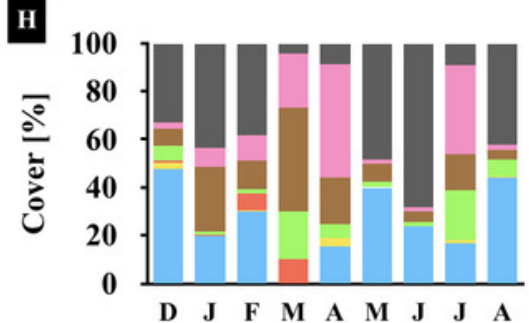




\section{Figure 5}

Canonical analyses of principal coordinates.

Canonical analyses of principal coordinates (CAP) indicating differences in the benthic assemblage composition (\% cover per taxa) at the study sites (Coqueiral, Gramuté, E. das Garças, and Costa Bela) and the contribution of meteo-oceanographic conditions (air and sea surface temperatures AirT/SST, chlorophyll-a concentration Chla, precipitable water Precip, salinity, and significant wave height SWH) and substrate rugosity. Vectors are based on Spearman correlation values $>0.5(p<0.5)$ for environmental variables and scores for taxa. The proportion of data explained by axis 1 and 2 are in parenthesis.

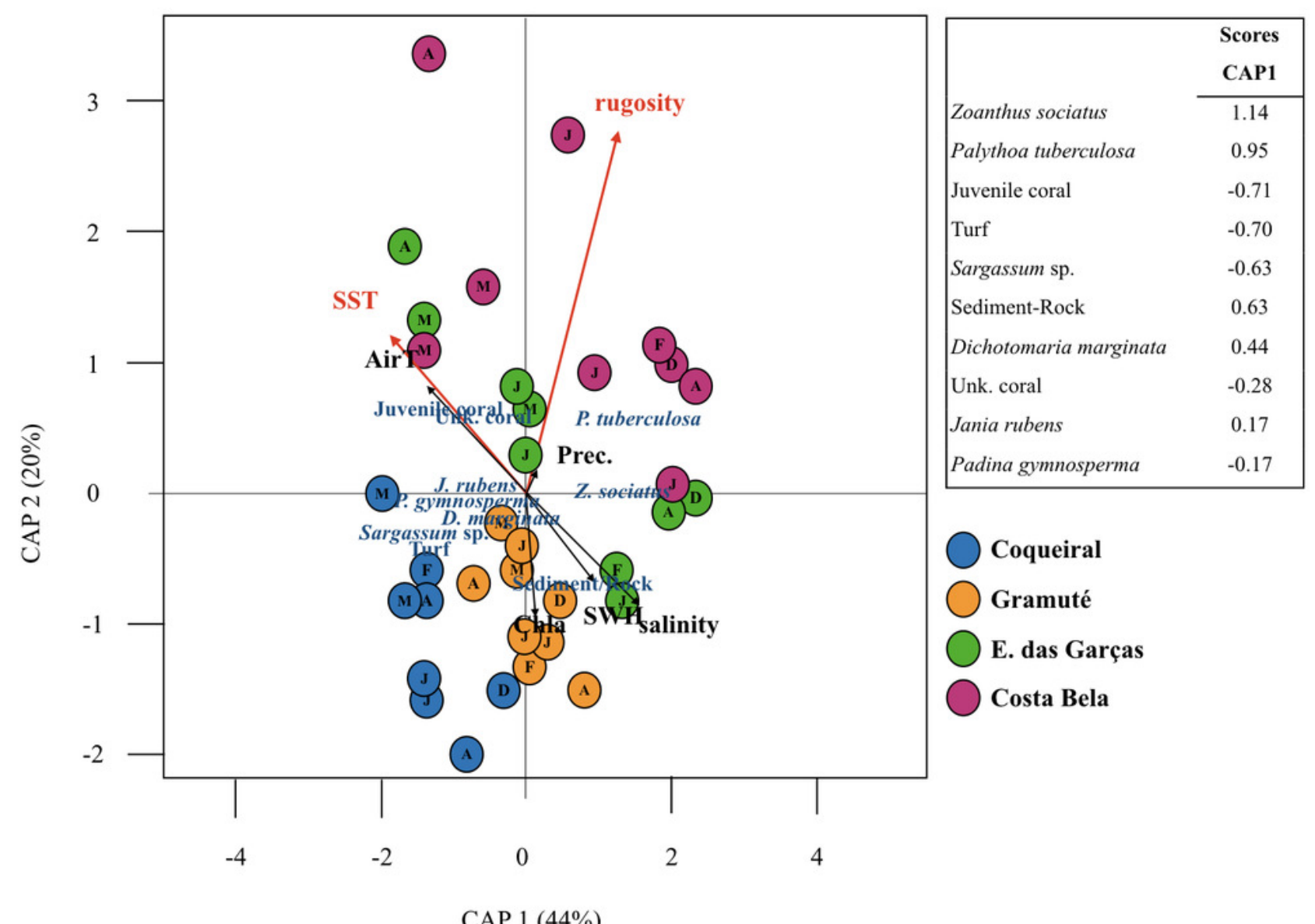




\section{Figure 6}

Climate projected changes in benthic reef biodiversity.

Projected regional (bottom) and site (Costa Bela A, Enseada das Garças B, Gramuté C, Coqueiral D) changes (\%) in the benthic biodiversity ( $\mathrm{H}^{\prime}$ Diversity, Shannon-Wiener Index S$W, R^{\prime}$ Richness number of species/taxon per quadrat per month, assemblage composition, variation in $\%$ Cover) with warming scenarios (sea surface temperature SST $+1^{\circ} \mathrm{C},+3^{\circ} \mathrm{C}$, -1 으. Note: sites are organized in relation to higher $(+)$ and lower (-) substrate rugosity. 


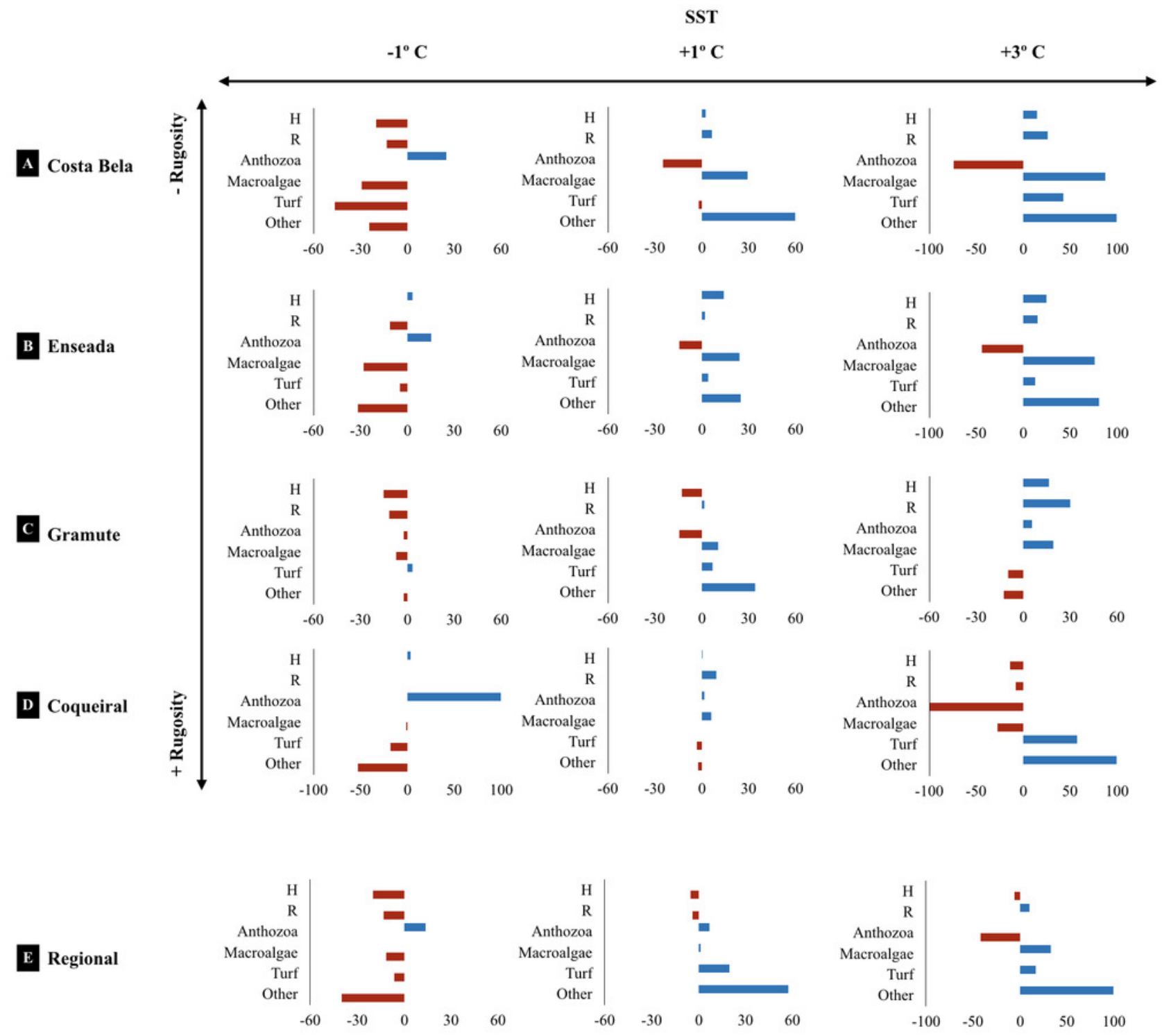




\section{Table $\mathbf{1}$ (on next page)}

Meteo-oceanographic variables monitored during the study.

Note: abbreviations, sources, and spatio-temporal resolutions are listed. 


\begin{tabular}{|c|c|c|c|}
\hline & Abbreviation & Source & $\begin{array}{l}\text { Spatio-temporal } \\
\text { resolution }\end{array}$ \\
\hline Air temperature & AirT & $\begin{array}{c}\text { NCEP NCAR } \\
\text { Reanalysis (Kalnay et } \\
\text { al., 1996) }\end{array}$ & $\begin{array}{c}\text { grid of } 2,5^{\circ} \text { latitude } x \\
\text { longitude }\end{array}$ \\
\hline $\begin{array}{l}\text { Sea surface } \\
\text { temperature }\end{array}$ & SST & $\begin{array}{l}\text { NOAA High-resolution } \\
\text { Blended Analysis of } \\
\text { Daily SST (Reynolds } \\
\text { et al., 2007) }\end{array}$ & $\begin{array}{l}\text { a grid of } 0.25^{\circ} \text { latitude } \\
\times 0.25^{\circ} \text { longitude }\end{array}$ \\
\hline $\begin{array}{l}\text { Precipitable } \\
\text { atmosphere water }\end{array}$ & Precipitation & $\begin{array}{c}\text { NCEP NCAR } \\
\text { Reanalysis (Kalnay et } \\
\text { al., 1996) }\end{array}$ & $\begin{array}{c}\text { grid of } 2,5^{\circ} \text { latitude } x \\
\text { longitude }\end{array}$ \\
\hline Ocean salinity & Salinity & $\begin{array}{c}\text { microwave imaging } \\
\text { radiometer on SMOS } \\
\text { mission's satellites } \\
\text { (CATDS database, } \\
\text { Jacquette et al.,2010) }\end{array}$ & $\begin{array}{c}\text { grid of } 0.25^{\circ} \text { latitude } x \\
0.25^{\circ} \text { longitude }\end{array}$ \\
\hline $\begin{array}{l}\text { Significant wave } \\
\text { height }\end{array}$ & SWH & Wave Watch III & $\begin{array}{c}\text { a grid of } 1^{\circ} \text { latitude } x \\
1^{\circ} \text { longitude }\end{array}$ \\
\hline $\begin{array}{l}\text { Sea surface } \\
\text { chlorophyll-a } \\
\text { concentration }\end{array}$ & Chla & $\begin{array}{c}\text { ocean color } \\
\text { radiometers on Modis- } \\
\text { Acqua satellite } \\
\text { (GIOVANNI database, } \\
\text { Acker \& Leptoukh, } \\
2007)\end{array}$ & $4 \mathrm{~km}^{2}$ grid \\
\hline
\end{tabular}




\section{Table 2 (on next page)}

Results of ANOVAs and PERMANOVAs comparing the variability in meteo-oceanographic conditions substrate rugosity, and benthic assemblage between months and/or among sites.

Meteo-oceanographic conditions: air and sea surface temperatures AirT and SST, Precipitation, Salinity, significant wave height SWH, chlorophyll-a concentrations Chla. Benthic assemblage measures: species cover (\%), diversity (Shannon-Wienner), and richness (number of taxa per quadrat per month). Note: $F$ for the statistics, df for degrees of freedom. Significant results $(p<0.05)$ are in bold. Data was log-transformed Log $x+1$ prior to the analyses. 


\begin{tabular}{|c|c|c|c|c|c|c|c|}
\hline \multirow[t]{2}{*}{ ANOVA } & \multicolumn{7}{|c|}{ PERMANOVA } \\
\hline & df & $\mathrm{F}$ & $p$ & & $d f$ & $\mathrm{~F}$ & $p$ \\
\hline $\begin{array}{l}\text { Meteo-oceanographic } \\
\text { conditions } \\
\text { AirT }\end{array}$ & & & & $\begin{array}{l}\text { Benthic } \\
\text { Assemblage } \\
\% \text { Cover }\end{array}$ & & & \\
\hline Month & 8 & 48.78 & $\begin{array}{c}< \\
0.0001\end{array}$ & Site & 3 & 87.58 & 0.01 \\
\hline Residual & 252 & & & Month & 7 & 20.78 & 0.01 \\
\hline SST & & & & $M * S$ & 21 & 8.51 & 0.01 \\
\hline $\begin{array}{r}\text { Month } \\
\text { Residual }\end{array}$ & $\begin{array}{c}8 \\
252\end{array}$ & 0.26 & 0.9760 & Residual & 96 & & \\
\hline Precipitation & 8 & 25.04 & $\begin{array}{c}< \\
0.0001\end{array}$ & Diversity & 3 & 8.67 & 0.01 \\
\hline Residual & 252 & & & Month & 7 & 7.88 & 0.01 \\
\hline $\begin{array}{r}\text { Month } \\
\text { Residual }\end{array}$ & $\begin{array}{c}8 \\
18\end{array}$ & 1.10 & 0.4072 & $\begin{array}{r}M^{*} S \\
\text { Residual }\end{array}$ & $\begin{array}{l}21 \\
96\end{array}$ & 5.14 & 0.01 \\
\hline $\mathrm{SWH}$ & & & & Richness & & & \\
\hline Month & 8 & 268.6 & $\begin{array}{c}< \\
0.0001\end{array}$ & Site & 3 & 11.95 & 0.01 \\
\hline Residual & 6048 & & & Month & 7 & 26.82 & 0.01 \\
\hline Chla & 3 & 384 & 0.0118 & $\begin{array}{r}M^{*} S \\
\text { Residual }\end{array}$ & $\begin{array}{l}21 \\
96\end{array}$ & 8.46 & 0.01 \\
\hline Month & 8 & 8.11 & 0.0001 & & & & \\
\hline $\begin{array}{r}M^{*} S \\
\text { Residual }\end{array}$ & $\begin{array}{c}24 \\
108\end{array}$ & 1.86 & 0.0165 & & & & \\
\hline Site & 3 & 14.34 & $\begin{array}{c}< \\
0.0001\end{array}$ & & & & \\
\hline Residual & 20 & & & & & & \\
\hline
\end{tabular}




\section{Table 3 (on next page)}

Results of canonical analyses of principal coordinates to evaluate the contribution of meteo-oceanographic conditions and benthic rugosity to month variations in the benthic assemblage composition.

Meteo-oceanographic conditions: air and sea surface temperatures AirT and SST, Precipitation, salinity, significant wave height SWH, chlorophyll-a concentrations Chla.

Benthic assemblage composition measure \% cover per taxa. Spearman correlation values for each environmental variable are described for in CAP axis 1-2. Note: proportion of variability explained by CAP axes are between parentesis '( $)$ ', F for statistic, significant results ( $p<$ $0.05)$ are in bold. 


\begin{tabular}{lcccc}
\hline & \multicolumn{3}{c}{$\mathrm{F}=1.72, p=0.002$} & \\
& CAP 1 & CAP 2 & $\mathrm{F}$ & $\mathrm{p}$ \\
& $(44 \%)$ & $(20 \%)$ & & \\
\hline AirT & -0.42 & 0.25 & 1.75 & 0.087 \\
SST & -0.58 & 0.37 & 1.99 & $\mathbf{0 . 0 5 2}$ \\
Precipitation & 0.02 & 0.04 & 1.03 & 0.393 \\
Salinity & 0.40 & -0.23 & 1.71 & 0.106 \\
SWH & 0.29 & -0.20 & 1.29 & 0.212 \\
Chla & 0.04 & -0.28 & 1.47 & 0.154 \\
Rugosity & 0.39 & 0.84 & 2.8 & $\mathbf{0 . 0 0 8}$ \\
\hline
\end{tabular}




\section{Table 4 (on next page)}

Results of canonical discriminant function analysis to assess the between-site differences according to meteo-oceanographic conditions and benthic assemblage composition.

Meteo-oceanographic conditions: sea surface temperatures SST. Benthic assemblage composition measure: \% cover per taxa. Note: linear discriminant coefficients LD1 and results of Jackknife re-samplings to test the accuracy of the classification for each site. 


\begin{tabular}{lclc}
\hline & LD1 & \multicolumn{1}{c}{ Site } & Accuracy \\
\hline SST & 0.32 & Coqueiral & $88 \%$ \\
Z. sociatus & 0.17 & Gramuté & $78 \%$ \\
P. tuberculosa & -0.02 & E. das Garças & $67 \%$ \\
Juvenile coral & 0.01 & Costa Bela & $56 \%$ \\
Turf & 0.06 & & \\
Sargassum sp. & 0.08 & & \\
Sediment-Rock & 0.04 & & \\
D. marginata & -0.31 & & \\
Unk. coral & 0.09 & & \\
J. rubens & 0.34 & & \\
P. gymnosperma & 0.06 & & \\
\hline
\end{tabular}

